\title{
Comparison of Exhaled Carbon Monoxide and Fagerstrom Test for Nicotine Dependency in Non- Cigarette Nicotine Addicts
}

\section{Sigara Dışı Nikotin Bağımlılarında Fagerstrom Nikotin Bağımlılık Testi ile E-CO Ölçümünün Karşılaştırılması}

\author{
${ }^{1}$ Bektaş Murat Yalçın, ${ }^{2}$ Esra Yalçın, ${ }^{3}$ Tevfik Fikret Karahan
}

\begin{abstract}
Introduction/Aim: Fagerstrom test for Nicotine Dependency (FNDT) is one of the most frequent tools used to assess the nicotine dependency in primary care. Today, apart from classical cigarette smoking many nicotine addicts may prefer other methods (e-cigarette, hookah, pipe, cigars, light cigarette users or directly tobacco users) to gather nicotine. The main aim of this study is to evaluate the effectiveness of FNDT in this non-classical nicotine addicts. Material and Methods: Among 550 volunteered patients who have administered to the OMU Family Medicine Departments smoking cessation clinic in 2019 have been divided into two groups (Study and control). The study group consisted of 62 (11.2\%) nicotine addicts who don't smoke cigarette (Non-classical) and $488(88.8 \%)$ cigarette smoker (classical) nicotine addict. Both groups' FNDT scores, their package year scores are calculated and their exhaled CO (E-CO) is measured. Then these results have been analyzed. Results: Among all of the subjects 388 were men (70.5\%). The mean age of the participants was $39,31 \pm 12,84$ years. Although there is no difference between the E-CO measurements between two groups (p>0,05), there was statistically difference between the mean scores of package/year and FNDT scores between the two groups $(\mathrm{t}=1.258, \mathrm{t}=2.014, \mathrm{p}<0.001$ respectively). There was a strong correlation between FNDT $(r=0,468)$ and package/year $(r=0,362)$ with E-CO in control group $(\mathrm{p}<0,001)$ while there was no statistical significance between FNDT $(\mathrm{r}=0.114)$ and package/ year $(\mathrm{r}=0.098)$ in study group $(\mathrm{p}=0.06)$. There was a statistically significant relation between E-CO with FNDT and package/year was observed in cigarette smokers (Control Group) ( $\mathrm{F}=35.305, \mathrm{p}<0.001)$.

Conclusion: Although FNDT is a very effective tool for assessing nicotine dependency for classical smokers, it may be not suited for all of the nicotine addicts. It may be useful to design and search new assessment methods for nicotine dependence in non-conventional smokers in primary care.

Keywords: Fagerstrom Test for Nicotine Dependency, Exhaled CO, Primary Care, Smoking Cessation

ÖZET

Amaç: Nikotin Bağımlılığı için Fagerstrom Testi (FNDT) birinci basamakta sigara bıraktırma pratiğinde sık kullanılan bir testtir. Günümüzde nikotin bağımlıları klasik sigara kullanımı yanında (Klasik) diğer yöntemlerle de (e-sigara, nargile, pipo, puro, hafif sigara kullanıcıları veya sarma sigara) de (Klasik olmayan) nikotin almayı tercih etmektedirler. Bu çalışmanın amacı klasik olmayan yöntem tercih eden nikotin bağımlılarında FNDT’nin etkinliğini araștırmaktır. Gerec ve Yöntemler: 2019 yılında OMU Aile Hekimliği Anabilim Dalı Sigara Bırakma Polikliniğine başvuran 550 gönüllü iki gruba (Çalışma ve kontrol) ayrıldı. Çalışma grubunu sigara kullanmayan (Klasik olmayan) 62 (\% 11,2) nikotin bağımlısı, kontrol grubunu ise sigara içen (Klasik) $488(\% 88,8)$ nikotin bağımlısı oluşturdu. Her iki grubun FNDT ve paket yılı puanları hesaplandıktan sonra ekspirium CO (E-CO) değerleri ölçülerek birbirleri ile karşılaştırıldı. Bulgular: Katılımcıların 388'i erkekti $(\% 70,5)$ ve yaş ortalaması $39,31 \pm 12,84$ yıl idi. İki grup arasında ortalama E-CO ölçümleri arasında fark olmamasına rağmen $(\mathrm{p}>0,05)$, paket / yıl ortalama skorları ile iki grup arasındaki FNDT skorları arasında istatistiksel olarak fark $\operatorname{vard} 1(t=1,258, t=2.014, p<0,001)$. Kontrol grubunda E-CO değerleri arasında FNDT ve $(r=0,468, p<0,001)$ paket $/$ yıl $(r=0,362, p<0,001)$ arasinda korelasyon izlenirken, çalışma grubunda FNDT $(r=0,114, p=0,06)$ ve paket/yıl $(r=0,098, p=0,089)$ arasında istatistiksel ilişki gözlenmedi. Sigara içen bağımlılarda (kontrol grubu) Lineer regresyon modelinde E-CO ile FNDT ve Paket/yıl arasında anlamlı istatistiksel ilişki izlendi ( $F=35,305$, $p<0,001)$.

Sonuç: FNDT klasik olarak sigara içenler için nikotin bağımlılığını değerlendirmede çok etkili bir araç olmasına rağmen, sigara dışı bir ürünle nikotin bağımlısı olan kişiler içenler için uygun olmayabilir. Birinci basamakta klasik sigara içmeyen nikotin bağımlıları için yeni değerlendirme yöntemleri tasarlamak ve araştırmak yararlı olabilir.

Anahtar Kelimeler: Nikotin Bağımlılı̆̆ı için Fagerstrom Testi, E-CO, Birinci basamak, Sigarayı Bırakma
\end{abstract}

Received / Geliştarihi: 12.10.2020, Accepted / Kabul tarihi: 07.04.2021

1'Ondokuz Mayis University Faculty of Medicine Department of Family Medicine, Samsun, Turkey MD.myalcin@omu.edu.tr

${ }^{2}$ Gazi State Hospital, Department of Neurology, Samsun, Turkey MD. esrayalcin75@gmail.com

${ }^{3}$ Avrasya University, Department of Physcology and Guidance Trabzon, Turkey. Fikretkarahan@hotmail.com

*Address for Correspondence / YazışmaAdresi:

Ondokuz Mayıs University Medical Faculty Department of Family Medicine Kurupelit/Samsun , TURKEY

Tel: +90 05531368827 e-mail: myalcin@omu.edu.tr.com

Yalçın BM, Yalçın E, Karahan TF. Sigara Dışı Nikotin Bağımlılarında Fagerstrom Nikotin Bağımlılık Testi ile E-CO Ölçümünün Karşılaştırılması.

TJFMPC, 2021;15(3): 472-478.

DOI: $10.21763 / \mathrm{tjfmpc.802741}$ 


\section{INTRODUCTION}

Smoking is one of the most important public health problems in Turkey. ${ }^{1}$ It is estimated that nearly 18 million people smoke daily in Turkey. ${ }^{2}$ Besides all of the efforts the outcomes for smoking cessation are rather low with professional help and medical aid (drugs or nicotine replacement therapy) the cessation rate exceed between $8-20 \%$ for the first six months. ${ }^{3}$ Although there are several thousand chemical substances that can be traced in smoke, among them nicotine is the reason for this very complex addiction with physical and psychological components. ${ }^{4}$ As a rule, primary care physicians evaluate their patients' nicotine addiction level by using several face-to-face surveys and laboratory findings. Urine cotinine and $\mathrm{CO}$ levels in exhaled air Carbon Monoxide measurements (E-CO) are the most preferred laboratory findings in order to evaluate nicotine dependency. ${ }^{5}$ There are several self-rated and face-to face surveys are present for to evaluate nicotine dependence in clinic. Fagerstrom Tolarance Questionnaire (FTQ), Fagerstrom Nicotine Dependency Test (FNTD), Heavy Smoking Index (HSI), Smoking Dependency Scale (CDS), Tobacco Dependency Search Scale (TDS), Nicotine Dependency Syndrome Scale (NDSS), Wisconsin Inventory of Smoking Dependency Motives (WISDM-68), Test to Assess the Psychological Dependency on Smoking (TAPDS) are most frequent which is used. ${ }^{6}$ Among these face-to-face tests; FNTD is one of the most frequent ones to prefer by the clinicians. FNTD is developed from FTQ and containing six questions. ${ }^{7}$ It has a higher reliability and validity score compared to FTQ in its original form. ${ }^{8}$ It is also known that FNTD is very practical in clinics compared to many other questionnaires. FNTD is also used for clinical decision-making for tobacco dependency treatment where it is recommended to plan nicotine addicts who have scores $\geq 7$ pharmacological treatment options (Bupropion or Varenicline). ${ }^{9}$ However, the tobacco industry offers new products in order to widen their customers. E-cigarettes, hookah, pipe, cigars, and light cigarettes are becoming ever more popular among nicotine addics. It is not surprising that FNTD may not be covering and adequate for all of the aspects of these nicotine products very well. The main aim of this study is to investigate the effectiveness of FNDT in classic cigarette nicotine addicts with non-classic nicotine addicts using E-CO readings as an independent factor.

\section{METHODS}

\subsection{Study Population and Design}

\section{Study Design}

This is an analytic descriptive study. Power analysis was performed in order to determine total number of participants. The Power is accepted as $80 \%$ (Type II error range 20\%). The minimal accepted level of Type I error range is accepted as $5 \%$. Power analyses revealed that a total of 163 subjects are necessary in order to perform this study. Among 550 volunteered patients who have administered to the OMU Family Medicine Department Smoking Cessation Clinic in 2019 have been accepted as study sample. Criteria for inclusion in the study were willing to take part, age $>18$ years, smoking at least for a year, intending to quit smoking within six months, not being on any psycho-regulatory medication (antidepressant, anxiolytic or antipsychotic), not having any psychiatric illnesses.

The standard smoking cessation approach of our outpatient clinic was applied to these subjects. ${ }^{10}$ Demographic data, smoking history and features [(FNDT), pack/year, age of onset, cessation attempts, etc.], anthropometric data [BMI and Waist Circumference] are collected from them. After their E-CO levels were measured a basic physical examination is performed. After appointing a cessation day lifestyle modifications are advised and if necessary pharmacological therapy is initiated based on their FNDT scores. Patients divided into two groups according to their type of nicotine product, which they use. The study group consisted of $62(11.2 \%)$ nicotine addicts (study group) who are not smoking cigarette (using primarily e-cigarette, hookah, pipe, cigars, light/slim cigarette or hand-wrapped tobacco users) while the control group consisted 488 (88,8\%) nicotine addicts smoking only cigarette (control group) regular classical cigarette smokers. As most of the participants in the study group start their nicotine addiction by cigarette smoking $(n=59$, 95\%) their package/year values were calculated from this period of time. Both groups' data have been compared and analyzed.

\subsection{Fagerstrom Nicotine Dependency Test (FNDT)}

The FNDT is a six-item self-report scale frequently used around the world to determine levels of nicotine addiction. ${ }^{7}$ Although the test is actually revised from the Fagerstrom tolerance test, it has better internal consistency and is more easily answered. In terms of the overall logic of this test, it is based on number of cigarettes smoked and length of smoking-free periods. In scoring the Fagerstrom Test for Nicotine Dependence, yes/no items are scored from 0 to 1 and multiple-choice items are scored from 0 to 3 . The instrument yields a dependency score between 0 (low) and 10 (high). Turkish version of the FNDT is studied by Uysal et al. ${ }^{11}$ The Turkish version of FTND had moderate reliability (Cronbach alpha $=0.56)$. 


\subsection{Exhaled Carbon Monoxide Measurements (E-CO)}

Exhaled CO concentration was measured using the EC50 Smokerlyser (Bedfont Instruments; Kent, UK). Bedfont EC50 analyzer is reported to correlate closely with blood carboxy hemoglobin concentration in smokers and in non-smokers, and it is an inexpensive, portable $\mathrm{CO}$ monitor that has previously been shown to be effective. ${ }^{12}$ The Smokerlyser measures breath CO levels in parts per million(ppm) based on the conversion of $\mathrm{CO}$ to carbon dioxide $(\mathrm{CO} 2)$ over a catalytically active electrode. ${ }^{13}$ Prior to the start of the study, the analyzer was calibrated with a mixture of $50 \mathrm{ppm}$ $\mathrm{CO}$ in air. The measurement of exhaled $\mathrm{CO}$ was done at all of the participants in their first visit. All of the participants are asked to exhale completely, inhale fully, and then hold their breath for 15 seconds before exhaling rapidly into disposable mouthpiece. Ambient CO levels were recorded before each breath. All of the E-CO measurements were performed at the first meeting, the participants who didn't smoke forat least eight hours were excluded from the study $(n=43)$.

\subsection{Statistical Analyses}

All of the data have been analyzed by SPSS version 16.0. A p-value of $<0,05$ is accepted as statistically significant. Several different statistical tests; independent-samples test, bivariate correlation, chisquare are performed in order to analyze the relation between two groups. Linear regression models were set in order to analyze the relation between E-CO with FNDT and package/year. (Ethical Permission: The ethical approval has been given by the Ondokuz Mayis University Ethical Committee.)

\section{RESULTS}

The demographic and smoking features of both groups are presented in Table 1. Among all of the participants 388 were men $(70.5 \%)$. The mean age of the participants was $39.31 \pm 12.84$ years. The distribution of different tobacco products (nonclassical) used by the study group by gender is shown in Table-2. Although there is no difference between the E-CO measurements between the two groups $(p>0.05)$, there was statistically difference between the mean scores of package/year and FNDT scores between two groups $(\mathrm{t}=1.258$, $\mathrm{t}=2.014, \mathrm{p}<0.001$ respectively). The comparison of mean FNDT and package/year in each group between each gender is presented in Table-3. In the study group, women participants had lower mean package/year and E-CO values $(p<0,01)$ compared to men although there was no difference between mean FNDT scores of both genders $(p>0,05)$ However in the control group women participants FNDT, E-CO and package/year values are significantly lower than the men participants. There was a strong correlation between FNDT $(r=0.468)$ and package/year $(\mathrm{r}=0.362)$ with $\mathrm{E}-\mathrm{CO}$ in control group $(p<0.001)$ while there was no statistical significance between FNDT $(\mathrm{r}=0.114)$ and package/ year $(r=0.098)$ in study group $(\mathrm{p}=0.06)$.

Linear regression models set for the relations between E-CO measurements (Dependent variable), FNDT and package/year (Independent variable) for both groups. In study group it was found that there wasn't a statistical relationship between E-CO levels, FNDT and package year $(\mathrm{F}=1,021$, $\mathrm{p}=0,103)$. This model is presented at Table-3. However, there was a statistical relationship between E-CO levels, FNDT and package year $(\mathrm{F}=35.305, \mathrm{p}<0.001)$ in control group $(\mathrm{R}=0.523$, $\mathrm{R}^{2}=0.273$, Durbin-Watson=2.145). The $\mathrm{R}^{2}$ value shows that $27 \%$ of the changes in $\mathrm{CO}$ values can be explained by FNDT and package/year variables in cigarette smokers (Study Group) means that The Linear regression model is presented in Table-4. 
Table 1: The comparison of demographic and smoking features of study and control groups.

\begin{tabular}{|l|c|c|c|c|}
\hline Variables & $\begin{array}{c}\text { Study Group } \\
(\mathbf{n = 6 2})\end{array}$ & $\begin{array}{c}\text { Control Group } \\
(\mathbf{n = 4 8 8})\end{array}$ & $\mathbf{~ t ~}$ & $\mathbf{p}$ \\
\hline Men & $43(69,4 \%)$ & $345(70,6 \%)$ & 0,987 & $\mathrm{p}=0,125^{*}$ \\
\hline Women & $19(30,6 \%)$ & $143(29,3 \%)$ & 1,101 & $\mathrm{p}=0,112^{*}$ \\
\hline FNitiation of smoking age (year) & $25,35 \pm 1,98$ & $26,37 \pm 1,98$ & 2,5987 & $\mathrm{p}<0,001^{*}$ \\
\hline Package/year (mean) & $3,2 \pm 1,4$ & $5,4 \pm 1,8$ & 3.251 & $\mathrm{p}<0,001^{*}$ \\
\hline E-CO*** (ppm) () & $10,9 \pm 1,5$ & $12,8 \pm 1,7$ & 2,998 & $\mathrm{p}=0,201^{*}$ \\
\hline
\end{tabular}

**FNDT: Fagerstrom Nicotine Dependency Test

***E-CO: Exhaled Carbon Monoxide Level

*IndependentSamplesT-Test

Table 2. Distribution of different tobacco products (non-classical) used by the study group by gender

\begin{tabular}{|l|c|c|c|}
\hline & Women & Men & Total \\
\hline Light/Slim Cigarettes & $16(80 \%)$ & $8(20 \%)$ & $22(35.5 \%)$ \\
\hline E-cigarette & $3(23.0 \%)$ & $10(76.9 \%)$ & $13(20.9 \%)$ \\
\hline Hookah & $2(25 \%)$ & $9(75 \%)$ & $12(19.3 \%)$ \\
\hline Hand-wrapped tobacco & $8(70 \%)$ & $4(30 \%)$ & $12(16.1 \%)$ \\
\hline Pipe & 0 & $3(100 \%)$ & $3(4.8 \%)$ \\
\hline
\end{tabular}

Table 3. The comparison of mean FNDT, package/year and E-CO values in

\begin{tabular}{|c|c|c|c|c|c|}
\hline \multicolumn{3}{|c|}{$\begin{array}{c}\text { Study Group } \\
\text { Women }=29,(46,7 \%) \\
\text { Men }=33,(53,2 \%)\end{array}$} & \multicolumn{3}{|c|}{$\begin{array}{c}\text { Control Group } \\
\text { Women }=133,(27,2 \%) \\
\text { Men }=355,(72,7 \%)\end{array}$} \\
\hline & Mean & $\mathbf{p}$ & & Mean & $\mathrm{p}$ \\
\hline $\begin{array}{l}\text { FNDT } \\
\text { Women } \\
\text { Men } \\
\end{array}$ & $\begin{array}{l}2,8 \pm 1,7 \\
3,5 \pm 2,7\end{array}$ & $\begin{array}{l}0,987 \\
0,587\end{array}$ & $\begin{array}{l}\text { FNDT } \\
\text { Women } \\
\text { Men }\end{array}$ & $\begin{array}{l}5,01 \pm 1,9 \\
6,41 \pm 0,7\end{array}$ & $\begin{array}{c}2,557 \\
0,01\end{array}$ \\
\hline $\begin{array}{l}\text { Package/year } \\
\text { Women } \\
\text { Men }\end{array}$ & $\begin{array}{c}7,52 \pm 2,4 \\
11,54 \pm 1,7\end{array}$ & $\begin{array}{c}1,257 \\
0,01\end{array}$ & $\begin{array}{l}\text { Package/year } \\
\text { Women } \\
\text { Men }\end{array}$ & $\begin{array}{c}9,28 \pm 2,1 \\
15,13 \pm 1,8\end{array}$ & $\begin{array}{c}10,417 \\
0,001\end{array}$ \\
\hline $\begin{array}{l}\text { E-CO } \\
\text { Women } \\
\text { Men }\end{array}$ & $\begin{array}{l}14,28 \pm 9,5 \\
22,47 \pm 2,7\end{array}$ & $\begin{array}{l}7,587 \\
0,001\end{array}$ & $\begin{array}{c}\text { E-CO } \\
\text { Women } \\
\text { Men }\end{array}$ & $\begin{array}{c}15,13 \pm 9,1 \\
24.28 \pm 15,75\end{array}$ & $\begin{array}{c}14,929 \\
0,001\end{array}$ \\
\hline
\end{tabular}

FNDT: Fagerstrom Nicotine Dependency Test

E-CO: Exhaled Carbon Monoxide Level

*IndependentSamplesT-Test 
Table 4: The linear regression model for relation between E-CO, FNDT and package/year in study group

\begin{tabular}{|c|c|c|c|c|c|c|c|}
\hline \multirow[b]{2}{*}{ Model } & \multicolumn{2}{|c|}{ Unstandardized Coefficients } & \multirow{2}{*}{\begin{tabular}{|c} 
Standardized \\
Coefficients
\end{tabular}} & \multirow[b]{2}{*}{$\mathrm{t}$} & \multirow[b]{2}{*}{ Sig.* } & \multicolumn{2}{|c|}{$95,0 \%$ Confidence Interval for B } \\
\hline & $\mathrm{B}$ & Std. Error & & & & Lower Bound & Upper Bound \\
\hline (Constant) & 2,529 & 2,453 & & 1,031 & ,304 & $-2,311$ & 7,368 \\
\hline $\mathrm{FNDT}^{* *}$ & 2,365 & 0,386 & 0,403 & 6,126 & 0,001 & 1,603 & 3,127 \\
\hline Package/year & 0,177 & 0,051 & 0,227 & 3,456 & 0,001 & 0,076 & 0,277 \\
\hline
\end{tabular}

a. Dependent Variable: E-CO

*FNDT: Fagerstrom Nicotine Dependence Test

*Linear Regression Model

Table 5: The linear regression model for relation between E-CO, FNDT and package/year in control group

\begin{tabular}{|c|c|c|c|c|c|c|c|}
\hline \multirow[b]{2}{*}{ Model } & \multicolumn{2}{|c|}{ Unstandardized Coefficients } & \multirow{2}{*}{\begin{tabular}{|l} 
Standardized \\
Coefficients \\
Beta \\
\end{tabular}} & \multirow[b]{2}{*}{$\mathrm{t}$} & \multirow[b]{2}{*}{ Sig.* } & \multicolumn{2}{|c|}{$95,0 \%$ Confidence Interval for B } \\
\hline & $\mathrm{B}$ & Std. Error & & & & Lower Bound & Upper Bound \\
\hline $\mathrm{FNDT}^{* *}$ & 0,1915 & 0,011 & 0,358 & 0,266 & 0,27 & 0,038 & 0,084 \\
\hline Package/year & 0,061 & 0,015 & 0,514 & 0,841 & 0,08 & 0,028 & 0,095 \\
\hline
\end{tabular}

a. Dependent Variable: E-CO

*FNDT: Fagerstrom Nicotine Dependence Test

*Linear Regression Model

\section{DISCUSSION}

Our study has revealed important results. Our results have implied that FNDT may be not suited for non-classical smokers based on E-CO measurements. Although the mean scores of E-CO measurements between the two groups weren't significantly different from each other, the FNDT scores of study group were 2.2 points (app.) lower than control group. Based on E-CO measurements these results indicate that the nicotine addiction level of these groups would be assed less severe in daily practice if only FNDT is considered. A clinician might recommend a less intensive treatment based on these results although they need an intensified approach.

FNDT was designed almost four decades ago and until then many different tobacco, products became more popular among smokers such as Ecigarettes. FNDT was mostly designed for regular classical cigarette smokers and depends on basic nicotine metabolism. After regular smokers smoke their last cigarette before sleep, the plasma nicotine levels drop due to their kidneys. When they wakeup their blood nicotine levels are the lowest point with a nicotine craving and most smokers get very pleased to increase their plasma nicotine levels as fast as possible. ${ }^{14}$ First question of the FNDT is investigating the urgency of this nicotine craving and ask time to first cigarette (or first nicotine replacement) from waking up. However, some smokers may smoke during their sleep time and don't let their total plasma nicotine levels drop too low. Second question of FNDT is about the amount of cigarettes per day. FNDT designed to assess the nicotine dependency based on the average number of cigarettes consumed in 24 hours. The average cigarette contains about 10 to $12 \mathrm{mg}$ nicotine (On the high end $28 \mathrm{mg}$ ) while a cigar contains 13.3$15.4 \mathrm{mg}$, e-cigarette $0.5-15.4 \mathrm{mg}$ (15 puffs), pipe 30.8-50.89 mg, chewing tobacco $144 \mathrm{mg}$ (a can) and hookah 1.04 (per puff). ${ }^{15}$ These non-classical products might be confusing while deciding the total amount of nicotine that addicts consume per day. Uysal \& Turan suggested to use FTND-ecig rather than FTND in E-cigarette users. ${ }^{16}$ They revised FTND suggested to use 15 puffs of ecigarettes for a cigarette in order to measure FTNDeciq. Also light cigarettes contain less amount of nicotine (6 mgr approx.) compared with regular cigarettes. ${ }^{17}$ This may cause that a mild nicotine addict has to smoke more light cigarettes in order to reach a satisfactory level of plasma nicotine level compared with regular cigarettes. We have added this group of smokers $(n=20)$ to the study group because of this reason. These two questions determine most of the score of FNDT (a total of six points) which we decide to intensify our approach (adding drugs for cessation) as levels of dependency increase. 
Measuring E-CO provides mostly an objective measure of patients' smoking status. ${ }^{18}$ Although the E-CO measurement device is not cheap; it could berather used easily with minimal training for primary care. In a recent study by Babaoğlu et.al ${ }^{19}$ it has been shown that there was a statistically significant correlation between FTND score and E-CO levels $(\mathrm{r}=0,233, \mathrm{p}<0.001)$. They report a weaker correlation than our results $(r=0.468)$. They also found that a cut-off score of $7.5 \mathrm{ppm}$ for exhaled CO may be useful as a marker for heavy smoking (FTND score $\geq 6$ ). However, they performed this study with regular classical smokers.

Our study may have some flaws. First of all, the participants in the control group was lower than expected due to the COVID-19 pandemic. The number of participants in the control group is well below the power analyses indicate. The hookah cafes and other places were closed during this period. Also, our study group consists of different types of non-classical nicotine addicts. Also, different genders prefer different products for example e-cigarette, hookah and pipe were more popular among men while women prefer light/slim cigarettes, and hand-wrapped tobacco most. It is known that in most cases women might have less nicotine addiction than men. This fact might cause heterogeneity in our data. Many nicotine addicts may not stick to just one product. It is possible that one nicotine product user might easily use another product (except e-cigarette users). For instance, a hookah addict might smoke cigarettes as well. Although we classified our research groups according to the tobacco product they use most frequently, this statement depends on the objectivity of the cases

In conclusion, as a result of our study, the effectiveness of FTND was found to be limited in non-classical nicotine addicts. it may be useful to design and search for new assessment methods including E-CO for these subjects.

\section{REFERENCES:}

1. Türkiye Halk Sağlığı Kurumu. Küresel Yetişkin Tütün Araştırması Türkiye 2012." "Sağlık Bakanlığı yayın no:948, Ankara: 2014;4-6.

2. Türkiye hastalık yükü çalışması 2004. Sağlık Bakanlığı, Refik Saydam Hıfzıssıhha Merkezi Başkanlığı, Hıfzıssıhha Mektebi Müdürlüğü, Sağlık Bakanlığı yayın no: 701 Ankara: Aydoğdu Ofset Matbaacılık, 2007;27.
3. WHO. Quitting tobacco. Tobacco Free Initiative (TFI). https://www.who.int/tobacco/quitting/summary _data/en (Last updated at:01/02/2019)

4. Siahpush $\mathrm{M}$ et al. Association between duration of use of pharmacotherapy and smoking cessation: findings from a national survey. BMJ Open 2015;5(1):e006229. DOI: 10.1136/bmjopen-2014-006229

5. Fritz M, Wallner R, Grohs U, Kemmler G, Saria , Zernig G. Comparable sensitivities of urine cotinine and breath carbon monoxide at follow-up time points of three months or more in a smoking cessation trial. Pharmacology 2010;85:234-40. DOI: 10.1159/000280435

6. Jarvis MJ, Tunstall-Pedoe H, Feyerabend C, Vesey C, Saloojee Y. Comparison of Tests Used to Distinguish Smokers from Nonsmokers. Am J Public Health 1987; 77:1435-8. DOI: 10.2105/ajph.77.11.1435

7. Heatherton TF, Kozlowski LT, Frecker RC, Fagerstrom KO. The Fagerstrom Test for Nicotine Dependence: a revision of the Fagerstrom Tolerance Questionnaire. $\mathrm{Br} \mathrm{J}$ Addict 1991; 86: 1119-27. DOI: 10.1111/j.1360-0443.1991.tb01879.x

8. Kozlowski LT, Porter CQ, Orleans CT, Pope MA, Heathertone T. Predicting smoking cessation with self-reported measures of nicotine dependence: FTQ, FTND, and HSI. Drug and Alcohol Dependence 1994; 34 (3): 211-6. DOI: 10.1016/0376-8716(94)90158-9

9. Cahill, K., Stevens, S., Perera, R., Lancaster, T., 2013. Pharmacological interventions for smoking cessation: An overview and network meta-analysis. Cochrane Database Syst. Rev. 31, 5:CD009329. doi: 10.1002/14651858.CD009329.pub2.

10. Yalcin BM, Unal M, Pirdal H, Karahan TF. Effects of an anger management and stress control program on smoking cessation: a randomized controlled trial. J Am Board Fam Med. 2014;27(5):645-60. DOI: 10.3122/jabfm.2014.05.140083

11. Uysal et. Al. Fagerstrom test for nicotine dependence: Reliability in Turkish sample and factor analysis. Tüberküloz ve Toraks Dergisi 2004;52(2):115-21

12. Andersson MF, Moller AM. Assessment of carbon monoxide values in smokers: a 
comparison of carbon monoxide in expired air and carboxyhaemoglobin in arterial blood. Eur J Anaesthesiol 2010; 27:812-8. DOI: 10.1097/EJA.0b013e32833a55ea

13. Jarvis MJ, Belcher M, Vessey C, Hutchison DCS. Low cost carbon monoxide monitors in smoking assessment. Thorax 1986;41:886-7. DOI: $10.1136 /$ thx. 41.11 .886

14. Benowitz NL, Jacob P. Effects of cigarette smoking and carbon monoxide on nicotine and cotinine metabolism. Clin Pharmacol Ther. 2000;67(6):653-9.

DOI: $10.1067 /$ mcp. 2000.107086

15. American Cancer Society Medical and Editorial Content Team. (2019). What do we know about e-cigarettes? http://cancer.org/cancer/cancer-causes/tobaccoand-cancer/e-cigarettes.html (Last update at:09/09/2020 )

16. Uysal MA, Turan A. Can Fagerstrom test for nicotine dependence be used to evaluate the nicotine dependence in electronic cigarette users? Turk Thoracj. 2019; 110

17. Cattamanchi A, Jewell T. Healthline. How much nicotine is in a cigarette and other tobacco products? https://www.healthline.com/health/how-muchnicotine-is-in-a-cigarette) (Last updated at: 01/05/2019)

18. Guan NC, Ann AY. Exhaled carbon monoxide levels among Malaysian male smokers with nicotine dependence. South Asian J Trop Med Pubklic Health. 2012; 43: 212-6. PMID: 23082572

19. Babaoğlu E, Karalezli A, Er M, Hasanoğlu HC, Öztuna D. Exhaled carbon monoxide is a marker of heavy nicotine dependence. Turk J Med Sci, 2016;46:1677-81. DOI:10.3906/sag1601-140 